\title{
OBITUARY
}

\section{Erlendur Haraldsson: An Appreciation}

\author{
JIM B. TUCKER \\ jbt8n@virginia.edu
}

https://10.31275/20212055

Creative Commons License CC-BY-NC

Erlendur Haraldsson, a prolific researcher who made a number of major contributions in various areas of parapsychology and survival research, died in Reykjavik, Iceland, on November 22, 2020, at the age of 89.

Born near Reykjavik, Erlendur studied philosophy in college, but his interest in understanding

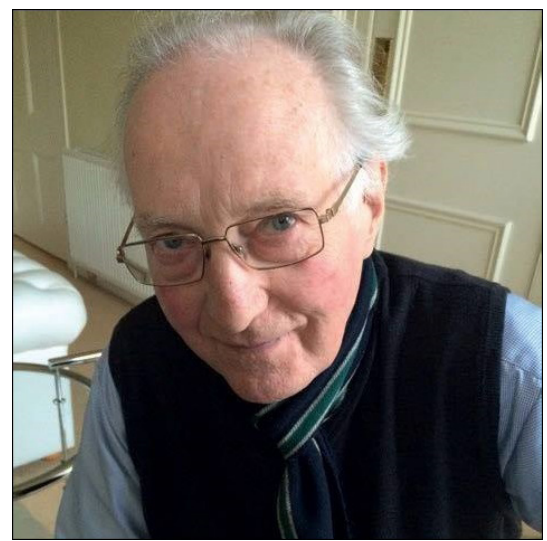
more about the world began before that. When he was 15, he had an experience during a heavy storm when the sun suddenly shone through the clouds and lit up pebbles on the banks of the nearby shore. As the light reflected off the pebbles, Erlendur sensed being filled with light himself in a way that was immense and beyond words. In an interview with Michael Tymn (2015), he said that a vivid trace of that feeling stayed with him forever and that after that, he never doubted that there was a superior reality.

Following college, he worked for three years, mostly as a journalist, before returning to school to study psychology, eventually earning a Ph.D. under Hans Bender in Freiburg, Germany. After that, he spent a year working at J. B. Rhine's parapsychology center in Durham, North Carolina, followed by an internship in clinical psychology at the University of Virginia, where he met lan Stevenson. He and Stevenson studied an Icelandic medium together, introducing Erlendur to the 
topic of mediumship to which he would return in subsequent decades.

Following his internship, he entered the field with a bang. Karlis Osis, the director of research of the American Society for Psychical Research, invited Erlendur to join him in a large study of deathbed visions. They surveyed hundreds of doctors and nurses in both the United States and India about events they had witnessed in their patients. What resulted was a landmark study, one that exemplified the best the field has to offer-detailed statistical analysis along with compelling individual reports. One striking example involved a twoand-a-half-year-old boy whose mother had died six months before. The respondent wrote, "He was lying there very quiet. He just sat himself up, and he put his arms out and said, 'Mama,' and fell back [dead]" (Osis \& Haraldsson, 1977, p. 53). Osis and Haraldsson found that the data did not support known medical or psychological causes of hallucinations. Likewise, the influences of religious or other cultural factors could not be used to explain away the phenomena.

When Tymn asked for the highlights of his career, Erlendur started with that study and then discussed his survey of psychic experiences and apparitions in Iceland. He worked on the European Values Survey, in which half of the respondents in Nordic countries said they believed in life after death and 43 percent believed in reincarnation (Haraldsson, 2006). In addition, 41 percent of respondents in Iceland reported personal experiences of contact with a deceased individual. Erlendur then led interviews of 450 people in Iceland who reported such experiences, and he published his findings in the book The Departed Among the Living (Haraldsson, 2012).

Erlendur's work with Icelandic mediums included his remarkable investigation of a sitting that Indiri Indridason held in Reykjavik in 1905 (Haraldsson \& Gerding, 2010). During the sitting, Indridason assumed a personality who said he was a Dane named Mr. Jensen. Jensen said he had just come from Copenhagen, which was 1300 miles away. (Indridason, who died when he was twenty-eight, had never been there.) He said he had seen a fire there and that a factory was burning. He gave various details that witnesses were only able to confirm when the next ship from Copenhagen brought newspapers that described the events surrounding the fire.

When Jensen appeared in subsequent sittings, he said his first 
name was Emil and that he was a manufacturer. No one tried to confirm his existence-until a hundred years later when Erlendur did. He searched the state and city archives in Copenhagen and found only one Emil Jensen who was registered as a manufacturer. In the 1885 census, he was living at Store Kongensgade 68, in the immediate vicinity of Store Kongensgade 63 where the fire broke out. He was last registered in 1898 , the year he died, at an address that was only some three hundred yards away.

Erlendur brought the same meticulousness to his study of children's purported past-life memories, which is where I intersected with him. We both followed in lan Stevenson's footsteps in the systematic study of the phenomenon. Along with researching some cases with lan, Erlendur independently investigated many more. Focusing on ones in Sri Lanka and Lebanon, he demonstrated the same dogged attention to detail that lan had, producing some very strong case reports. One involved a little boy in Sri Lanka named Duminda, who made the unlikely claim to have been a senior Buddhist monk who nonetheless enjoyed a red car, a moneybag, and a radio. Rejecting a journalist's quick identification of a deceased man whose life was a very imprecise match for the boy's statements, Erlendur worked until he honed in on one particular monk from the 1920s. He had been at the temple that Duminda named, and he had in fact owned the items Duminda remembered (except that it was a gramophone he owned, not a radio) (Haraldsson \& Samararatne, 1999). In another, a Sri Lankan girl gave details about an incense maker who had been killed nearly 150 miles away, including the names of the two incense brands he sold, ones that were not available in the area where she and her family lived (Haraldsson, 2000).

Erlendur also moved beyond the study of individual cases to explore aspects of the phenomenon that no one had previously investigated. He did extensive psychological testing of children in both Sri Lanka and Lebanon, comparing those who reported memories of past lives with others who did not (Haraldsson, 1997, 2003; Haraldsson et al., 2000). He was also the first to systematically interview the children when grown up, as he met with adults he or Stevenson had originally studied when they were children (Haraldsson, 2008; Haraldsson \& Abu-Izzedin, 2012). 
Erlendur recently reviewed his work with past-life memories in a book he wrote with James Matlock, I Saw a Light and Came Here. He concluded that the reincarnation theory best fit the data and the various features of the cases. From there, he proposed a circular/spiral model of human life's progression: circular as life is followed by death is followed by life, but also, we might hope, a spiral, as humanity's development gradually moves along a slow, ever-widening path of progress (Haraldsson \& Matlock, 2017).

I've only scratched the surface of Erlendur's efforts over his many years. You can learn more from Matlock (2020) and Tymn (2015). Or you can read Erlendur's publications themselves, as listed on his website at https://notendur.hi.is/erlendur/english/. But it may take you a whilethere are more than 350 of them.

What a career. And what a contribution he made.

\section{REFERENCES}

Haraldsson, E. (1997). A psychological comparison between ordinary children and those who claim previous-life memories. Journal of Scientific Exploration, $11(3), 323-335$.

Haraldsson, E. (2000). Birthmarks and claims of previous-life memories: I. The case of Purnima Ekanayake. Journal of the Society for Psychical Research, 64(1), 16-25. https://www.academia.edu/258437/Birthmarks_and_Claims_ of_Previous_Life_Memories_I_The_Case_of_Purnima_Ekanayake

Haraldsson, E. (2003). Children who speak of past-life experiences: Is there a psychological explanation? Psychology and Psychotherapy: Theory, Research and Practice, 76(1), 55-67.

Haraldsson, E. (2006). Popular psychology, belief in life after death, and reincarnation in the Nordic countries, Western and Eastern Europe. Nordic Psychology, 58(2), 171-180.

Haraldsson, E. (2008). Persistence of past-life memories: Study of persons who claimed in their childhood to remember a past life. Journal of Scientific Exploration, 22, 385-393.

Haraldsson, E. (2012). The departed among the living: An investigative study of afterlife encounters. White Crow Books.

Haraldsson, E., \& Abu-Izzedin, M. (2012). Persistence of "past-life" memories in adults in Lebanon who, in their childhood, claimed memories of a past life. Journal of Nervous and Mental Disease, 200(11), 985-989.

Haraldsson, E., \& Gerding, J. L. F. (2010). Fire in Copenhagen and Stockholm: Indridason's and Swedenborg's "remote viewing" experiences. Journal of 
Scientific Exploration, 24(3), 425-436.

Haraldsson, E., \& Matlock, J. G. (2017). I saw a light and came here: Children's experiences of reincarnation. White Crow Books.

Haraldsson, E., \& Samararatne, G. (1999). Children who speak of memories of a previous life as a Buddhist monk: Three new cases. Journal of the Society for Psychical Research, 63, 268-291.

Haraldsson, E., Fowler, P. C., \& Periyannanpillai, V. (2000). Psychological characteristics of children who speak of a previous life: A further field study in Sri Lanka. Transcultural Psychiatry, 37(4), 525-544.

Matlock, J. G. (2020). Erlendur Haraldsson. In Psi Encyclopedia. The Society for Psychical Research. https://psi-encyclopedia.spr.ac.uk/articles/erlendur-haraldsson Osis, K., \& Haraldsson, E. (1977). At the hour of death. Avon.

Tymn, M. (2015). An interview with Dr. Erlendur Haraldsson. http://whitecrowbooks. com/michaeltymn/entry/an_interview_with_dr._erlendur_haraldsson 